\author{
Rafał Prostak* \\ Cracow University of Economics, Cracow, Poland \\ https://orcid.org/0000-0002-4772-4597
}

\title{
The Fertility Rate in the EU Societies and Life Satisfaction of Contemporary Europeans
}

\section{Introduction}

Over the past six decades, mankind has tripled its numbers, surpassing 7.5 billion in 2011. The population of the European Union is also growing, but this growth is relatively low. In the years 2011-2016, it did not exceed $0.4 \%$ in annual terms. What is more, in 2010 even a decline in the number of the EU residents was confirmed $(-0.04 \%)$ (Eurostat, 2019b). The relatively small increase in the number of EU residents is due to the very unfavourable fertility rate, amounting to only 1.59 , while it is estimated that the substitutability of generations in developed countries is not threatened with a factor exceeding the value of 2.1. None of the EU Member States currently reaches this level. The best situation in this respect is observed in France, where in 2017 the number of 1.9 children per woman of childbearing age was recorded. The averaged age of the European Union female residents expecting the offspring is also unfavourable (30.7 in 2017; in the case of the first-born child -29.1), which shows a sustained upward trend (Eurostat, 2019b). Thus, the fertility rate does not guarantee the substitutability of generations to the EU societies, and yet the number of the European Union inhabitants is growing. The reasons for this state of affairs should be sought elsewhere. This is the effect of immigration. The external immigration ${ }^{1}$ in the EU has been rapidly gaining momentum since the 1990s, effectively compensating for the shrinking population of Europeans born in the Member States. The EU population is also positively affected by the increase in the life expectancy of the Member States inhabitants, especially in Western societies (Eurostat, 2017).

The lack of substitutability of generations in EU societies is related to cultural changes taking place therein. Although it is convincing, it raises a number of vital questions:

${ }^{1}$ Immigration from non-EU countries, which is distinguished from internal immigration being the effect of intra-EU migratory movements of EU citizens, enjoying the freedom (legal rights guaranteed by treaties) to settle in any EU country.

\footnotetext{
* Correspondence address: Katedra Stosunków Międzynarodowych, Uniwersytet Ekonomiczny w Krakowie, Pawilon “Ustronie”, 31-510 Kraków (Kraków-Śródmieście), ul. Rakowicka 27, e-mail: prostakr@uek.krakow.pl.
} 
how to identify the elements of this culture, exercising such a strong impact on the procreative decisions of the EU residents; whether it is possible to estimate the power and durability of the impact of such factors, especially in the case of particular EU societies; at what rate and to what extent the external immigrants are vulnerable to the impact of such factors. Culture is characterized by constant variability, which makes our attempts at describing it fail, and additionally makes it difficult to assess the impact of specific cultural patterns on the decisions made by individual people and entire societies. Aware of the difficulties associated with examining such a complex matter as the cultural patterns and the power of their impact, the author limits the present study to the issue of low fertility of the EU residents in relation to their sense of satisfaction with life.

If we agree that it is a natural need of a person to have children, the lack of them will constitute a significant deficit, negatively affecting life satisfaction. Of course, we should clarify here whether it is a need for self-fulfillment of a man/woman functioning as a parent for one person or for many persons. Such a low fertility rate in the EU societies is due to the universal resignation from parenthood (voluntary childlessness) as $\mathrm{such}^{2}$. At the same time, if we confirm the high life satisfaction of the European Union inhabitants, who are characterized by a low fertility rate, we face another series of questions, namely whether it is really a human natural need to have children; alternatively, whether the cultural patterns of modern European societies effectively suppress what is natural; and finally, how, if it is possible at all, one can affect culture so that the need to have children again becomes the primary desire of the European Union inhabitants.

An attempt to face the above-mentioned questions should be preceded by confirming the correlation between the life satisfaction and a low fertility rate in the European Union countries. This is the objective of this study. The primary source of information consists here in selected Eurobarometer reports in which the collected data were subject to secondary analysis. The findings were then confronted with a description of the demographic situation in Poland and the social perception of successful life in our country. The relevant data were provided by the Centrum Badania Opinii Społecznej (Public Opinion Research Center; CBOS).

\section{Parenthood as a human need}

In Abraham Maslow's pyramid of needs, procreation is placed at its foundations, alongside with food, shelter (housing), leisure and warmth (including clothing), as well as other biological (physiological) human needs which possess a basic character, because their satisfaction constitutes a human fundamental pursuit. In the hierarchy of needs, the biological ones precede the needs for security (the need for stabilization), affiliation needs (social needs), respect and recognition (the need for social approval and distinc-

2 About childlessness as a social phenomenon read in (Dolińska, 2014; Cieślińska, 2014; Komorowska, Kukawska, 2015; Slany, Szczepaniak-Wiecha, 2003; Szukalski, 2003). 
tion) and self-actualization (the need for knowledge, aesthetic experience and realization of one's ambitions). Maslow classifies the biological and security needs as "lowerlevel" needs, and others as "higher-level" ones (Maslow, 1990: 72-92).

In Bronisław Malinowski’s concept, seven basic human needs are distinguished: (1) metabolism; (2) reproduction; (3) appropriate physical conditions; (4) security; (5) movement; (6) development; (7) health. They correspond to seven types of socio-cultural behaviour (patterns, constructions) that serve the realization of distinguished needs: (re:1) food production, its distribution and consumption; (re:2) getting married, giving birth and raising children, maintaining family ties; (re:3) production and use of clothing, construction and use of housing; (re:4) protection instinct, imperative to provide assistance and actual providing of assistance, organization of public and social security institutions; (re:5) work, going for walks, active involvement in sport, tourism; (re:6) education, participation in culture; (re:7) hygiene, health prophylaxis, healthy living, rational leisure. Although Malinowski's typology of basic needs, unlike that proposed by Maslow, is not hierarchically ordered but is arranged linearly, listing the reproduction as the second in turn may suggest its importance for the author (Malinowski, 2000: 101).

Kazimierz Obuchowski, in turn, distinguishes two basic human needs: (1) self-preservation (physiological needs); and (2) preservation of the species (need for reproduction). Thus, for Obuchowski, reproduction is not a physiological need directly related to the condition of a particular person. It becomes a need representing a collective value (survival of the species), which means that parenthood (its objective and meaning) is subject to a specific "socialization" - while sexual activity itself, in Obuchowski's view, does not constitute activity that would be indispensible for life, nor for life that brings satisfaction. In addition to the needs of self-preservation and preservation of the species, Obuchowski distinguishes orientation needs (cognitive needs, emotional contact needs, and life sense needs), psychological distance needs, and also sexual needs (Obuchowski, 2000: 130-134).

Comparing the findings of Obuchowski and Maslow, we can notice that the former is inclined to give the collective (species) dimension to the need for reproduction, whereas in the case of the latter such solution is not formulated. Malinowski, in turn, presents the typology of needs in the perspective of the individual's functioning in a specific social context (cultural phenomena), and consequently all needs identified by him basically assume a social (cultural) dimension. As he emphasizes:

We will apply this term [need] not to the individual organism, but rather to the community and its culture as a whole. Therefore, by needs I understand a system of conditions in the human organism, in the cultural system and in relation of both to the natural environment which is necessary and sufficient for the survival both a group and the individual. Thus, the need constitutes a limiting set of facts. Habits and their motivations, learned reactions and foundations of organization have to adopt such system so that the basic needs are satisfied (Malinowski, 2000: 101). 
For Malinowski, childbirth and upbringing of children constitute cultural and socially reinforced patterns, fulfilling the basic need for reproduction and the development of society. Based on the above-mentioned typologies of needs, we can confirm the diversity of perceptions concerning the role of reproduction in a set of human needs.

\section{Fertility, satisfaction with life of the European Union inhabitants, and the conditions for its achievement}

The fertility rate in the Member States of the European Union has remained at a low level for several years (Table 1).

Table 1. The fertility rate in the EU in 2001-2017

\begin{tabular}{|c|c|c|c|c|c|}
\hline & 2001 & 2007 & 2010 & 2015 & 2017 \\
\hline EU & 1.46 & 1.56 & 1.62 & 1.58 & 1.59 \\
\hline Belgium & 1.67 & 1.82 & 1.86 & 1.7 & 1.65 \\
\hline Bulgaria & 1.21 & 1.49 & 1.57 & 1.53 & 1.56 \\
\hline Czech Republic & 1.15 & 1.45 & 1.51 & 1.57 & 1.69 \\
\hline Denmark & 1.74 & 1.84 & 1.87 & 1.71 & 1.75 \\
\hline Germany & 1.35 & 1.37 & 1.39 & 1.5 & 1.57 \\
\hline Estonia & 1.32 & 1.69 & 1.72 & 1.58 & 1.59 \\
\hline Greece & 1.25 & 1.41 & 1.48 & 1.33 & 1.35 \\
\hline Spain & 1.23 & 1.38 & 1.37 & 1.33 & 1.31 \\
\hline France & 1.9 & 1.98 & 2.03 & 1.96 & 1.9 \\
\hline Ireland & 1.94 & 2.01 & 2.05 & 1.85 & 1.77 \\
\hline Italy & 1.25 & 1.4 & 1.46 & 1.35 & 1.32 \\
\hline Cyprus & 1.57 & 1.44 & 1.44 & 1.32 & 1.32 \\
\hline Latvia & 1.22 & 1.54 & 1.36 & 1.7 & 1.69 \\
\hline Lithuania & 1.29 & 1.36 & 1.5 & 1.7 & 1.63 \\
\hline Luxemburg & 1.66 & 1.61 & 1.63 & 1.47 & 1.39 \\
\hline Hungary & 1.31 & 1.32 & 1.25 & 1.45 & 1.54 \\
\hline Malta & 1.48 & 1.35 & 1.36 & 1.37 & 1.26 \\
\hline The Netherlands & 1.72 & 1.71 & 1.79 & 1.66 & 1.62 \\
\hline Austria & 1.38 & 1.38 & 1.44 & 1.49 & 1.52 \\
\hline Poland & 1.31 & 1.31 & 1.41 & 1.32 & 1.48 \\
\hline Portugal & 1.45 & 1.35 & 1.39 & 1.31 & 1.38 \\
\hline Romania & 1.27 & 1.45 & 1.59 & 1.62 & 1.71 \\
\hline Slovenia & 1.21 & 1.38 & 1.57 & 1.57 & 1.62 \\
\hline Slovakia & 1.2 & 1.27 & 1.43 & 1.4 & 1.52 \\
\hline Finland & 1.73 & 1.83 & 1.87 & 1.65 & 1.49 \\
\hline Sweden & 1.57 & 1.88 & 1.98 & 1.85 & 1.78 \\
\hline Great Britain & 1.6 & 1.86 & 1.92 & 1.8 & 1.74 \\
\hline Croatia & 1.46 & 1.48 & 1.55 & 1.4 & 1.42 \\
\hline
\end{tabular}

Source: own elaboration based on (Eurostat, 2019a: 5). 
In 2017, the lowest result was recorded in Malta (1.26), Spain (1.31) and Italy (1.32); the highest in France (1.9), Sweden (1.78) and Ireland (1.77). In the case of as many as sixteen Member States, the fertility rate was equal to or lower than the EU average.

At the same time, the social research confirms the general satisfaction of EU citizens with the lives they lead. The Standard Eurobarometer 89 report (spring 2018) indicates that $83 \%$ of respondents confirm their satisfaction with life, while $16 \%$ declare their dissatisfaction. In the "satisfied" group, 23 p.p. are "very satisfied", while the remaining ones are "quite satisfied". Among the "dissatisfied" only 3 p.p. are "totally dissatisfied with their lives". The proportion of the "satisfied" and "dissatisfied" has been slightly changed over the last eighteen years (Public, 2018: 4). Danes declare the highest satisfaction with their lives (99\%), Bulgarians - the lowest (47\%). In addition to Danes, more than $90 \%$ of the Irish, Dutch, Finnish, Swedish, Luxemburgers, Britons, Germans, Austrians, Maltese, Slovenes and Belgians confirm their satisfaction with life. In the fifth decentile, Bulgarians are accompanied only by Greeks (Table 2).

king for an answer to the question about the reasons for the differences in the "satisfied" and "dissatisfied" proportions in particular EU countries, we should determine the conditions for achieving satisfaction in the lives of the inhabitants of these countries. The Eurobarometer 279, Poverty and Exclusion published in 2007, is helpful here3. Herein, we find the results of a public opinion poll, in which the respondents were asked to indicate - from the list of eleven conditions of a successful life - the one of the key importance for them. The respondents were also allowed to give their own preferences, going beyond the indicated catalogue (Figure 1).

Only $4 \%$ of respondents indicated having children, while as many as $45 \%$ related life satisfaction to having a good job. It is also worth noting that $15 \%$ of respondents related good life to having a good relationship with a life partner, and 14\% linked the achievement of good life to good education. Equally important impact on successful life as parenting turned out to be free time and the ability to enjoy it. The need for respect and acceptance by the social environment gained a better score by two percentage points than the desire to have children.

The results of the above-mentioned research allow us to draw a conclusion about the dominant role of good work in the contemporary view on conditions for achieving a satisfying life in contemporary societies of the EU Member States. In turn, the dependence of achieving satisfaction with life on having children is relatively rare. This observation leads to a conclusion that there is a significant dissonance between the Maslow's and Malinowski's findings, and the EU contemporary inhabitants' idea of life giving satisfaction. Probably, such a low appreciation of parenthood in the image of a successful life would not be a surprise for Kazimierz Obuchowski.

3 The document quoted in this study was developed more than a decade ago. Unfortunately, we do not have newer comprehensive research results on this subject. 
Table 2. Satisfaction with life of the EU residents in 2018 (\%)

\begin{tabular}{|l|c|c|c|c|c|c|}
\hline & $\begin{array}{c}\text { I. very } \\
\text { satisfied } \\
\text { with life }\end{array}$ & $\begin{array}{c}\text { II. quite } \\
\text { satisfied } \\
\text { with life }\end{array}$ & $\begin{array}{c}\text { sum I i II } \\
\text { (satisfied } \\
\text { with life) }\end{array}$ & $\begin{array}{c}\text { III. totally } \\
\text { dissatisfied } \\
\text { with life }\end{array}$ & $\begin{array}{c}\text { IV. Rather } \\
\text { dissatisfied } \\
\text { with life }\end{array}$ & $\begin{array}{c}\text { sum III i IV } \\
\text { (dissatisfied } \\
\text { with life) }\end{array}$ \\
\hline UE & 23 & 60 & 83 & 3 & 13 & 16 \\
\hline Belgium & 26 & 64 & 90 & 2 & 8 & 10 \\
\hline Bulgaria & 7 & 40 & 47 & 14 & 35 & 49 \\
\hline Czech Republic & 20 & 67 & 87 & 2 & 11 & 13 \\
\hline Denmark & 72 & 27 & 99 & 1 & 0 & 1 \\
\hline Germany & 32 & 60 & 92 & 1 & 7 & 8 \\
\hline Estonia & 17 & 66 & 83 & 3 & 13 & 16 \\
\hline Greece & 6 & 42 & 48 & 17 & 35 & 52 \\
\hline Spain & 18 & 66 & 84 & 3 & 13 & 16 \\
\hline France & 20 & 67 & 87 & 3 & 10 & 13 \\
\hline Ireland & 42 & 55 & 97 & 0 & 3 & 3 \\
\hline Italy & 5 & 61 & 66 & 6 & 27 & 33 \\
\hline Cyprus & 32 & 53 & 85 & 3 & 12 & 15 \\
\hline Latvia & 15 & 60 & 75 & 4 & 21 & 25 \\
\hline Lithuania & 15 & 55 & 70 & 4 & 25 & 29 \\
\hline Luxemburg & 39 & 55 & 94 & 2 & 3 & 5 \\
\hline Hungary & 9 & 64 & 73 & 5 & 22 & 27 \\
\hline Malta & 25 & 67 & 92 & 1 & 7 & 8 \\
\hline The Netherlands & 56 & 41 & 97 & 0 & 3 & 3 \\
\hline Austria & 38 & 54 & 92 & 1 & 7 & 8 \\
\hline Poland & 15 & 72 & 87 & 1 & 9 & 10 \\
\hline Portugal & 5 & 70 & 75 & 3 & 22 & 25 \\
\hline Romania & 7 & 50 & 57 & 7 & 36 & 43 \\
\hline Slovenia & 26 & 64 & 90 & 1 & 9 & 10 \\
\hline Slovakia & 14 & 60 & 74 & 6 & 19 & 25 \\
\hline Finland & 33 & 63 & 96 & 0 & 4 & 4 \\
\hline Sweden & 45 & 51 & 96 & 0 & 4 & 4 \\
\hline Great Britain & 42 & 51 & 93 & 1 & 6 & 7 \\
\hline Croatia & 12 & 58 & 70 & 6 & 24 & 30 \\
\hline & & & 53 & & 3 & \\
\hline
\end{tabular}

Source: the author's development based on the Standard Eurobarometer 89, Report Public opinion in the European Union (Public, 2018: 6).

The data concerning the social recognition of living conditions in individual Member States are also seem to be interesting (Table 3). When asked about the key criterion of a successful life, $35 \%$ of Dutch people indicated a good relationship with a life partner, $22 \%$ - the acceptance and respect of the social environment, and 9\% - a good job. The same percentage of respondents indicated leisure and the ability to enjoy it. Parenthood was recognized by only $1 \%$ of the Dutch as the most important condition for 


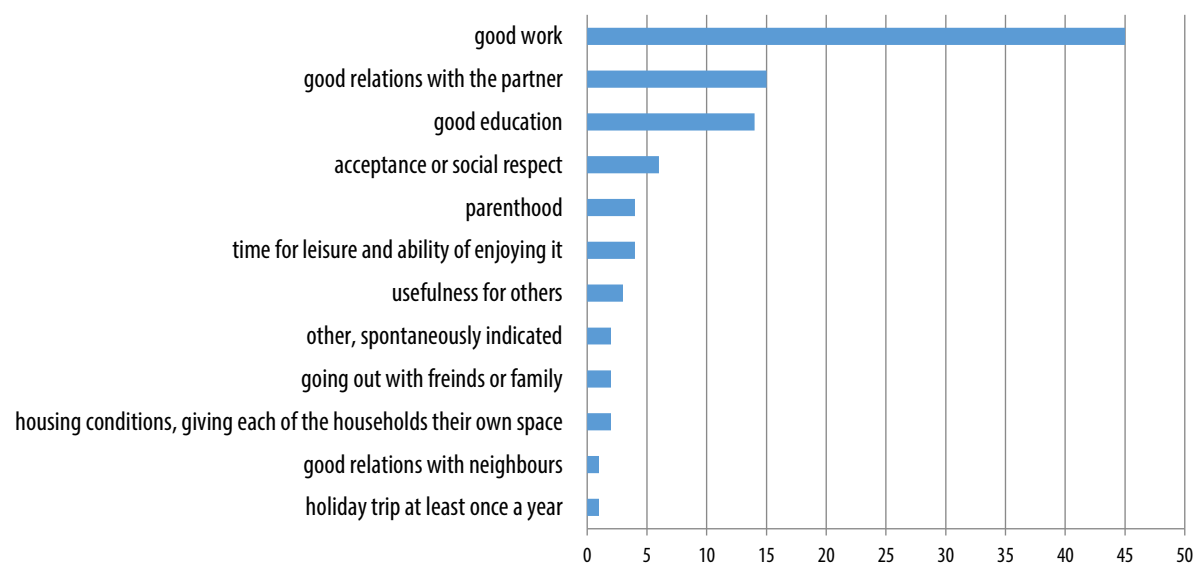

Figure 1. The most important condition of successful life in the UE inhabitants opinions (\%)

Source: the author's development based on the Eurobarometr 279, Poverty and Exclusion (Special, 2019: 4).

a successful life. For Croats, having children was in second place (with a share of 11\%). The same percentage was reached by parenthood in Finland and Sweden, with the third and fourth place respectively in the ranking. Having children was indicated in the third place in France, with this answer percentage among the French respondents being lower and amounting to $8 \%$. In Denmark, parenthood took the fourth place, after good relations with a partner (28\%), social recognition and respect (17\%), good job (14\%), and good education (12\%). This criterion was indicated by $7 \%$ of Danes. In Polish society, the first place was taken by a good job (54\%); the next was good education (16\%), and the third - good relationship with a life partner (12\%). Having children turned out to be crucial only for $3 \%$ of Poles. It is also worth noting that for Hungarians, providing each household member with their own space turns out to be more important $(6 \%)$ than parenting (5\%).

Having children as the most important condition for a good life in none of the EU societies was indicated by more than $11 \%$ of respondents (the result for Sweden, Finland and Croatia), while in three countries the result was 1\% (Estonia, Lithuania, The Netherlands). Let us repeat, the dominating condition for a successful life in the EU societies today turns out to be having a good job.

In turn, when respondents were asked to indicate the second basic condition for a successful life, $18 \%$ of the surveyed EU citizens indicated parenting. In this ranking, having children took the fourth place (Figure 2). 
Table 3. The most important condition for a successful life in the opinion of particular societies EU Member States (\%)

\begin{tabular}{|c|c|c|c|c|c|c|c|c|c|c|c|c|}
\hline & 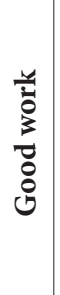 & 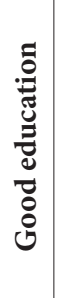 & 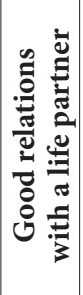 & 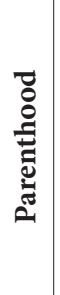 & 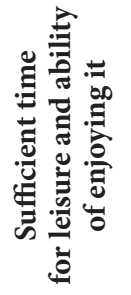 & 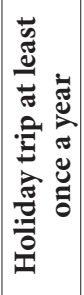 & 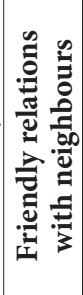 & 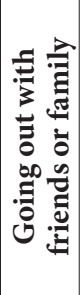 & 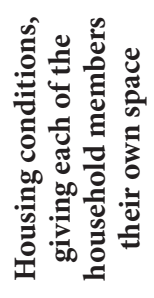 & 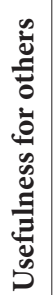 & 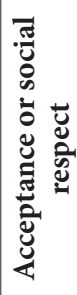 & 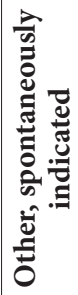 \\
\hline Belgium & 39 & 9 & 22 & 3 & 6 & - & 2 & 2 & 2 & 5 & 7 & 3 \\
\hline Bulgaria & 62 & 11 & 11 & 5 & 1 & 1 & - & - & 1 & 2 & 3 & 1 \\
\hline Czech Republic & 47 & 14 & 18 & 4 & 3 & - & 1 & 1 & 4 & 4 & 2 & 2 \\
\hline Denmark & 14 & 12 & 28 & 7 & 7 & 1 & 1 & 4 & - & 7 & 17 & 2 \\
\hline Germany & 49 & 19 & 15 & 4 & 2 & 1 & 1 & 1 & 1 & 1 & 5 & 1 \\
\hline Estonia & 43 & 31 & 9 & 1 & 5 & 1 & 2 & 1 & 1 & 2 & 2 & 2 \\
\hline Greece & 56 & 10 & 11 & 6 & 4 & - & 1 & 1 & - & 2 & 5 & 4 \\
\hline Spain & 48 & 15 & 9 & 3 & 5 & 1 & - & 2 & 2 & 1 & 5 & 8 \\
\hline France & 49 & 5 & 12 & 8 & 4 & 2 & 2 & 3 & 2 & 5 & 6 & 1 \\
\hline Ireland & 33 & 24 & 13 & 4 & 8 & - & 2 & 3 & 2 & 2 & 4 & 2 \\
\hline Italy & 58 & 14 & 9 & 3 & 3 & 1 & - & 1 & 2 & 2 & 4 & 1 \\
\hline Cyprus & 51 & 14 & 19 & 2 & 3 & 1 & - & - & - & 1 & 7 & 2 \\
\hline Latvia & 47 & 23 & 10 & 6 & 1 & - & 1 & 1 & 1 & 4 & 4 & 1 \\
\hline Lithuania & 60 & 16 & 5 & 1 & 3 & 2 & 2 & 1 & 2 & 2 & 3 & 3 \\
\hline Luxemburg & 39 & 22 & 15 & 4 & 2 & 1 & 1 & 3 & 1 & 3 & 6 & 2 \\
\hline Hungary & 52 & 5 & 10 & 5 & 4 & 3 & 2 & 1 & 6 & 2 & 5 & 5 \\
\hline Malta & 32 & 27 & 19 & 2 & 5 & 1 & 2 & 2 & - & 2 & 6 & 2 \\
\hline The Netherlands & 9 & 7 & 35 & 1 & 9 & 1 & 1 & 4 & 2 & 5 & 22 & 3 \\
\hline Austria & 38 & 25 & 18 & 4 & 5 & 1 & 1 & 1 & 2 & - & 4 & 1 \\
\hline Poland & 54 & 16 & 12 & 3 & 1 & 1 & 1 & 1 & 1 & 3 & 4 & 2 \\
\hline Portugal & 39 & 10 & 14 & 4 & 6 & 2 & 2 & 4 & 2 & 4 & 4 & 5 \\
\hline Romania & 62 & 12 & 7 & 3 & 2 & 1 & 1 & - & 2 & 3 & 4 & 2 \\
\hline Slovenia & 35 & 16 & 21 & 8 & 6 & 1 & 1 & 1 & - & 3 & 5 & 1 \\
\hline Slovakia & 45 & 14 & 17 & 5 & 3 & 1 & 1 & - & 3 & 4 & 4 & 2 \\
\hline Finland & 15 & 7 & 48 & 11 & 6 & 1 & 1 & 1 & 1 & 3 & 3 & 3 \\
\hline Sweden & 17 & 5 & 33 & 11 & 10 & - & - & 2 & 1 & 3 & 15 & 1 \\
\hline Great Britain & 25 & 22 & 19 & 5 & 8 & - & - & 3 & 2 & 4 & 7 & 1 \\
\hline Croatia & 50 & 9 & 11 & 11 & 6 & - & - & 1 & 1 & 2 & 2 & 5 \\
\hline
\end{tabular}

Source: the author's development based on the Eurobarometer 279, Poverty and Exclusion, table QB1a (Special, 2019). 


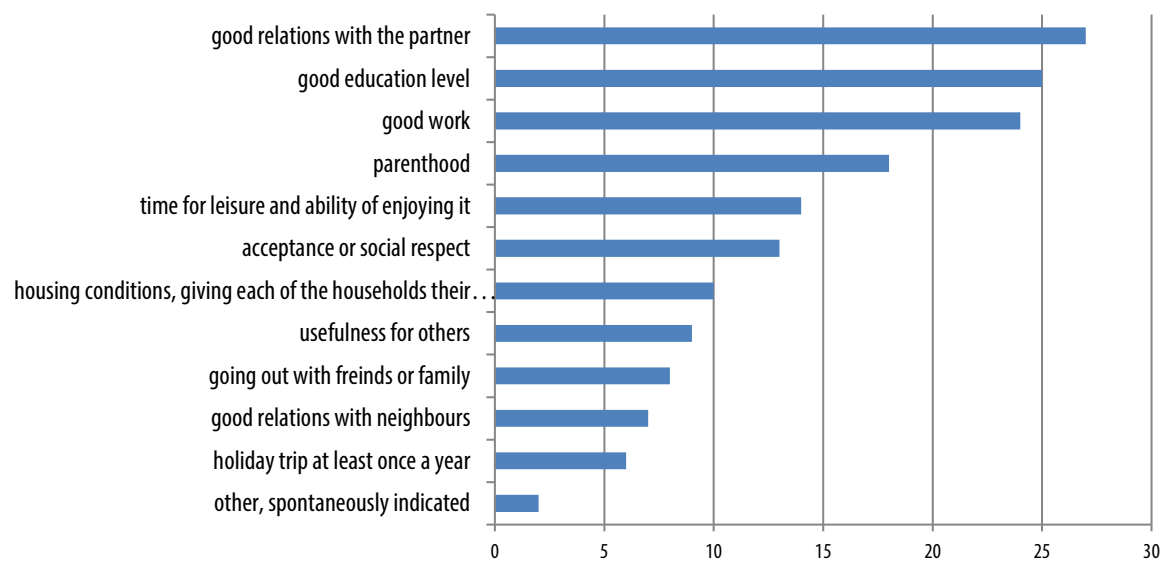

Figure 2. The second most important condition for a successful life in the opinion of the EU residents (\%)

Source: the author's elaboration based on the Eurobarometer 279, Poverty and Exclusion (Special, 2019: 5).

The aggregated data from Figure 1 and Figure 2 allow us to formulate a thesis that having children is the first or second priority condition for a successful life only for $22 \%$ of the EU residents. In the case of a good job, this value is 69 , good relations with a life partner -42 , good education -39 . The need for parenting only slightly exceeds the sum of the first and second priority need for acceptance or respect by the social environment (19\%), and time for leisure and ability to enjoy it (18\%).

When we refer to the situation in the societies of particular Member States, the results are as follows (Table 4).

Summing up the parenting indications as the primary or secondary need, in the case of Finnish respondents we get a score of 52; for Croatia it will be 39; for Sweden - 37; and for Denmark - 36 (Table 5). These data suggest that the fertility rate recorded in these countries should be relatively high in relation to the indications specific to other Member States. However, this intuition does not find practical confirmation. In 2007, the fertility rate in Denmark, Sweden and Finland4 was in the 1.83-1.88 range, while in

4 It is worth paying attention to a significant change in the demographic situation of Finland. In this country, the fertility rate fell from 1.83 in 2010 to 1.49 in 2017 . Such a large decrease was not recorded in any of the EU Member States. The largest increase occurred in the Czech Republic: from 1.15 in 2001 to 1.69 in 2017 (Table 1). 
Table 4. The second most important condition for a successful life in the opinion of particular societies of the EU Member States (\%)

\begin{tabular}{|c|c|c|c|c|c|c|c|c|c|c|c|c|}
\hline & $\begin{array}{l}u \\
\vdots \\
3 \\
3 \\
0 \\
0 \\
0 \\
0\end{array}$ & 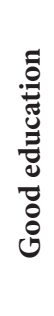 & 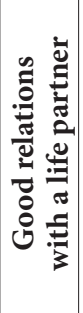 & 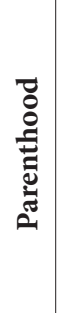 & 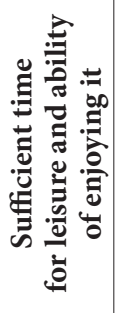 & 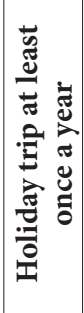 & 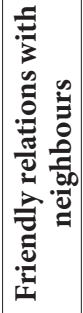 & 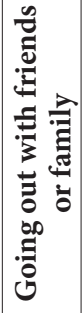 & 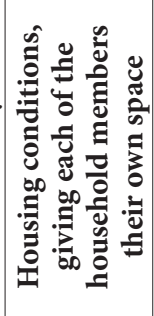 & 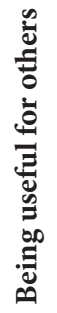 & 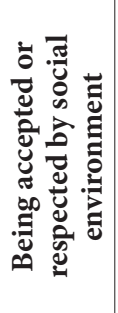 & 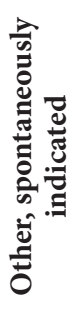 \\
\hline Belgium & 25 & 16 & 31 & 19 & 18 & 4 & 7 & 7 & 9 & 11 & 13 & 2 \\
\hline Bulgaria & 25 & 33 & 34 & 26 & 8 & 4 & 5 & 3 & 10 & 11 & 15 & 1 \\
\hline Czech Republic & 23 & 16 & 30 & 17 & 11 & 3 & 5 & 3 & 16 & 8 & 4 & 1 \\
\hline Denmark & 33 & 18 & 28 & 27 & 18 & 4 & 5 & 11 & 2 & 16 & 17 & 1 \\
\hline Germany & 28 & 31 & 39 & 22 & 10 & 4 & 8 & 5 & 7 & 4 & 13 & 1 \\
\hline Estonia & 32 & 31 & 23 & 9 & 18 & 7 & 6 & 6 & 8 & 10 & 9 & 2 \\
\hline Greece & 29 & 30 & 39 & 24 & 19 & 6 & 4 & 7 & 5 & 10 & 14 & 1 \\
\hline Spain & 26 & 27 & 25 & 12 & 19 & 4 & 4 & 9 & 5 & 6 & 11 & 8 \\
\hline France & 21 & 10 & 21 & 24 & 13 & 10 & 7 & 14 & 12 & 14 & 15 & 1 \\
\hline Ireland & 31 & 34 & 22 & 15 & 19 & 6 & 10 & 11 & 8 & 8 & 11 & 1 \\
\hline Italy & 18 & 33 & 22 & 14 & 12 & 5 & 4 & 7 & 12 & 5 & 10 & 1 \\
\hline Cyprus & 30 & 34 & 39 & 17 & 21 & 8 & 6 & 6 & 1 & 11 & 21 & 1 \\
\hline Latvia & 30 & 31 & 21 & 25 & 12 & 4 & 3 & 6 & 7 & 14 & 13 & 1 \\
\hline Lithuania & 22 & 38 & 17 & 8 & 10 & 14 & 7 & 4 & 10 & 11 & 12 & 1 \\
\hline Luxemburg & 29 & 24 & 24 & 15 & 10 & 4 & 8 & 12 & 10 & 9 & 19 & 1 \\
\hline Hungary & 18 & 11 & 27 & 17 & 18 & 11 & 7 & 7 & 23 & 7 & 11 & 2 \\
\hline Malta & 34 & 37 & 27 & 8 & 18 & 6 & 7 & 8 & 4 & 12 & 19 & 2 \\
\hline The Netherlands & 24 & 13 & 27 & 10 & 22 & 3 & 7 & 12 & 8 & 21 & 21 & 1 \\
\hline Austria & 26 & 21 & 32 & 18 & 16 & 5 & 5 & 6 & 10 & 2 & 13 & 1 \\
\hline Poland & 22 & 34 & 23 & 14 & 8 & 5 & 7 & 6 & 10 & 9 & 11 & 1 \\
\hline Portugal & 19 & 17 & 24 & 13 & 17 & 10 & 10 & 17 & 10 & 12 & 13 & 3 \\
\hline \begin{tabular}{|l} 
Rumania \\
\end{tabular} & 22 & 32 & 28 & 19 & 15 & 8 & 5 & 3 & 15 & 7 & 15 & 1 \\
\hline Slovenia & 29 & 21 & 30 & 23 & 18 & 4 & 10 & 4 & 4 & 8 & 15 & 2 \\
\hline Slovakia & 26 & 19 & 30 & 20 & 11 & 6 & 5 & 6 & 19 & 11 & 12 & 0 \\
\hline Finland & 34 & 13 & 25 & 41 & 18 & 3 & 9 & 7 & 5 & 11 & 7 & 1 \\
\hline Sweden & 35 & 13 & 34 & 26 & 25 & 3 & 6 & 8 & 2 & 15 & 21 & 1 \\
\hline Great Britain & 26 & 26 & 22 & 15 & 19 & 5 & 10 & 12 & 10 & 10 & 17 & 0 \\
\hline Croatia & 25 & 20 & 31 & 28 & 17 & 5 & 10 & 8 & 9 & 10 & 13 & 3 \\
\hline
\end{tabular}

Source: the author's development based on the Eurobarometer 279, Poverty and Exclusion, table QB1b (Special, 2019). 
Croatia it was only 1.48. Thus, the EU Nordic countries were below France and Ireland in this index The fertility rate in Croatia was clearly lower than the EU average (1.56), which is especially noteworthy here. At the same time, the aggregated need for offspring as a key condition for a successful life in the case of the French respondents amounted to $32 \%$, but in the case of the Irish residents it was relatively low, and amounted only to $19 \%$.

On the other hand, the Dutch, who extremely rarely noticed the condition for a successful life in parenthood (aggregated value: 11), showed a relatively high fertility rate: at 1.71 level. In comparison, the sum of percentage shares of the Maltese who indicated parenthood as a primary or secondary condition for a successful life was nearly equal to the Dutch result (value 10), but the fertility rate was much lower there (1.35). The lowest fertility rate in 2007 was recorded in Slovakia (1.27), although the Slovaks attributed greater importance to parenthood in achieving a life giving satisfaction (aggregated value: 25$)$ than the Dutch.

When the above presented data are compared with the indicator of life satisfaction of particular Member States residents, we also do not receive unambiguous results, as life satisfaction is most often confirmed by the inhabitants of Scandinavian countries, where we note a relatively high fertility rate and an above-average indication of parenthood as a primary or secondary condition for a successful life. On the other hand, the Maltese also commonly declare satisfaction with their lives, with a very low fertility rate and a slight recognition of the role of parenthood in achieving a good life. Our doubts are exacerbated by the example of France and Ireland, where the fertility rate in 2007 was the highest among the EU countries, the level of life satisfaction comparable with Malta (France) or much higher (Ireland), and dependence on achieving satisfaction more common than in the case of the Maltese. Again, an attempt to capture the dependences in the parameters adopted by us is additionally complicated by the Dutch example: with a relatively high fertility rate (1.77) and a very high life satisfaction ratio (97\%), we observe a very low recognition of the role of parenthood in achieving it.

Considering the above, it can be assumed that parenthood does not play a significant role in achieving a good and satisfying life in the societies of the EU Member States: we do not observe a simple relationship between fertility, life satisfaction and recognition of the role of parenthood in its attainment. Still, the Poverty and Exclusion Eurobarometer report points to the relationship between the feeling of economic security and the assessment of the quality of life in the opinion of the EU Member States residents, which confirms the importance of good work in this assessment. In addition, it is worth emphasising here that if life satisfaction had to do with fertility and recognition of the role of parenthood, the situation in the EU still would not be very optimistic. After all, in the 
Table 5. Parenting as a condition for a successful life, satisfaction with life and the fertility rate in the EU in 2007

\begin{tabular}{|c|c|c|c|c|c|}
\hline & $\begin{array}{l}\text { I. Parenthood - } \\
\text { the most important } \\
\text { condition (\%) }\end{array}$ & $\begin{array}{l}\text { II. Parenthood - } \\
\text { the second } \\
\text { most important } \\
\text { condition }(\%)\end{array}$ & $\begin{array}{c}\text { Sum } \\
\text { of I i II }\end{array}$ & $\begin{array}{c}\text { Life } \\
\text { satisfaction }\end{array}$ & $\begin{array}{c}\text { Fertility } \\
\text { rate }\end{array}$ \\
\hline UE & 4 & 18 & 22 & 80 & 1,56 \\
\hline Belgium & 3 & 19 & 22 & 89 & 1,82 \\
\hline Bulgaria & 5 & 26 & 31 & 36 & 1,49 \\
\hline Czech Republic & 4 & 17 & 21 & 82 & 1,45 \\
\hline Denmark & 7 & 27 & 34 & 97 & 1,84 \\
\hline Germany & 4 & 22 & 26 & 86 & 1,37 \\
\hline Estonia & 1 & 9 & 10 & 78 & 1,69 \\
\hline Greece & 6 & 24 & 30 & 67 & 1,41 \\
\hline Spain & 3 & 12 & 15 & 88 & 1,38 \\
\hline France & 8 & 24 & 32 & 82 & 1,98 \\
\hline Ireland & 4 & 15 & 19 & 90 & 2.01 \\
\hline Italy & 3 & 14 & 17 & 74 & 1,4 \\
\hline Cyprus & 2 & 17 & 19 & 87 & 1,44 \\
\hline Latvia & 6 & 25 & 31 & 63 & 1,54 \\
\hline Lithuania & 1 & 8 & 9 & 65 & 1,36 \\
\hline Luxemburg & 4 & 15 & 19 & 92 & 1,61 \\
\hline Hungary & 5 & 17 & 22 & 51 & 1,32 \\
\hline Malta & 2 & 8 & 10 & 82 & 1,35 \\
\hline The Netherlands & 1 & 10 & 11 & 97 & 1,71 \\
\hline Austria & 4 & 18 & 22 & 84 & 1,38 \\
\hline Poland & 3 & 14 & 17 & 77 & 1,31 \\
\hline Portugal & 4 & 13 & 17 & 62 & 1,35 \\
\hline Romania & 3 & 19 & 22 & 53 & 1,45 \\
\hline Slovenia & 8 & 23 & 31 & 91 & 1,38 \\
\hline Slovakia & 5 & 20 & 25 & 72 & 1,27 \\
\hline Finland & 11 & 41 & 52 & 94 & 1,83 \\
\hline Sweden & 11 & 26 & 37 & 97 & 1,88 \\
\hline Great Britain & 5 & 15 & 20 & 89 & 1,86 \\
\hline Croatia & 11 & 28 & 39 & 72 & 1,48 \\
\hline
\end{tabular}

Source: the author's development based on the Eurobarometer 279, Poverty and Exclusion, tables QB1a and table QB1b (Special, 2019): Standard Eurobarometer 67, p. 13; Eurostat (Fertility, 2019, p. 5).

case of Scandinavian countries, where almost everyone declares a satisfaction with life, the fertility rate does not guarantee the substitutability of generations.

The above data are worth confronting with the results of the research included the in Eurobarometer 273, European Social Reality, published in February 2007. It notes that 
six out of ten adult EU residents live with a life partner, and $68 \%$ of adults have children. In turn, close to $3 / 4$ adults without children (73\%) would like to have them (Standard Eurobarometer 273, 2007: 16). It can be concluded that these people feel a kind of parenting deficit. At the same time, in the face of research on the conditions of a successful life and general satisfaction with life of the EU citizens, the thesis is legitimate that this deficit does not significantly affect the general assessment of the quality of life and its conditions in social perception.

\section{Satisfaction with life and fertility in Poland}

According to the CBOS report of 2012 (CBOS, 2012), almost all respondents declared their willingness to have children. Only four out of a hundred questioned respondents said that they would rather not have any children. $10 \%$ of respondents declared their will to have one child, and almost half of the respondents (49\%) wanted two children (CBOS, 2012). Meanwhile, fertility in Poland has remained at the level below the EU average since the beginning of the century.

At the same time, $75 \%$ of respondents confirm their satisfaction with life, and another 21 are moderately satisfied with life (CBOS, 2018). In the same year, in the Eurobarometer 88 report it was recorded that life satisfaction among Polish respondents amounted to $85 \%$, by 2 p.p. more than the average for the European Union. $18 \%$ of respondents were very satisfied, while quite satisfied 67\% (Standard, 2018: 8).

Let us remind that only $3 \%$ of Polish respondents considered parenthood as the basic condition for a successful life in 2007 , and $14 \%$ - as the second most important one. The respondents definitely more often indicated good work - $54 \%$ and $22 \%$ respectively. Meanwhile, in the CBOS research on satisfaction with particular aspects of life, satisfaction with children invariably occupies the first place in the ranking (over $90 \%$ of parents), while job satisfaction occupies only the fourth place, giving way to a relationship with a spouse (permanent partner), relationship with friends (with acquaintances), and satisfaction with the place of residence. The distance between satisfaction with children and the sense of satisfaction with a professional career has been maintained for over two decades in the range from 24 p.p. up to $46 \mathrm{pp}$ (Table 6) (CBOS, 2019: 4).

Interpreting the data collected by the CBOS in the perspective of the results presented in the Eurobarometer 279 report, we can argue that, although the Poles definitely more often consider having a good job as a condition for a successful life than having the offspring, being the parent most commonly constitutes a source of life satisfaction in the Polish society, and satisfaction with professional work is noticeably lower (a clear increase in satisfaction with this aspect of life in the period of Poland's membership in the $\mathrm{EU}$ is worth noting: from the level of $57 \%$ in 2004 to the level of $71 \%$ in 2018). 


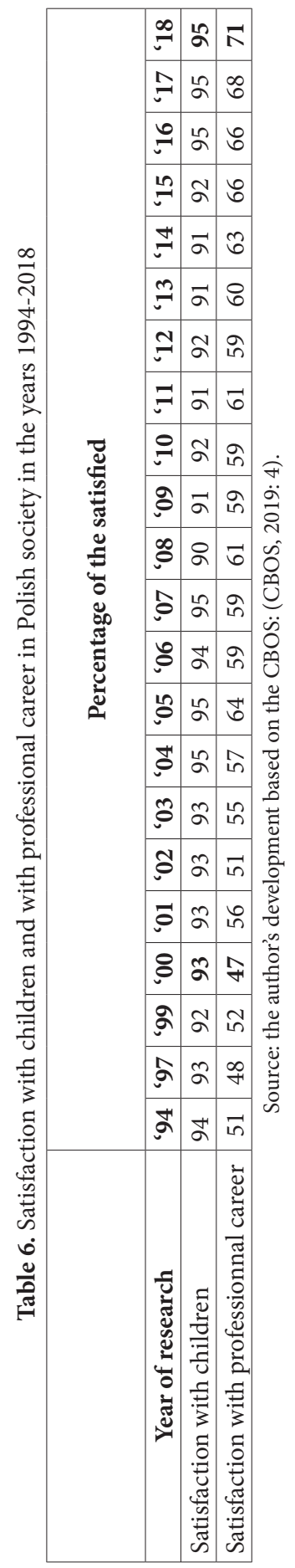




\section{Conclusion}

In the Enlightenment epoch, in Western civilization, making efforts to live a satisfying life was considered as a fundamental right. In the Virginia Declaration of Rights authored by George Mason, and in the United States Declaration of Independence, edited by Thomas Jefferson - both documents written in 1776 - the right to "pursuit of happiness" is presented as a natural human right, which can be treated as a modern, political and legal emanation of the ancient conviction about the natural tendency (predisposition) of man in his pursuit of happiness (Gr. eudaimonia). In the Political Liberalism, one of the most important works of contemporary political philosophy, John Rawls exposes the political role of the subjective right of participants in liberal democracies wishing to live a life worth living, stressing the differences between them concerning the images of such life. Pluralism is an immanent feature of the societies of "free and equal" people, as Rawls writes (Rawls, 1993). Although we generally want to give our existence meaning and value, we do it in a way that suits our preferences as to the conditions for a successful life. In other words, the universal goal is implemented with the help of particularly selected means. The Eurobarometer reports referred to in this paper confirm the widespread satisfaction with life of the EU societies members. Just as importantly, only a small percentage of the EU citizens links life satisfaction to parenthood recognizing it as a first-rate need (from 1 to $11 \%$ ). The most popular criterion is having a good job (from 9 to $62 \%$ ). On the other hand, based on the example of the Polish society, although few Poles consider having children as a key to achieve a "good life" (only $3 \%$ in 2007), currently people with offspring find the greatest source of satisfaction in their children (95\% in 2018; the same number in 2007). Looking for life satisfaction mainly in professional activity (54\% of respondents in 2007), we achieve it less frequently in practice ( $71 \%$ in $2018,59 \%$ in 2007$)$.

To sum up, parenting is neither a primary nor a secondary condition for a good (successful and satisfying) life in the opinion of the decisive majority of the European Union residents. Satisfaction with life is not dependent on the fact of having children. This state of affairs predicts the deepening unfavourable demographic trends, since the fertility rate in the Member States does not ensure the substitutability of generations. Nevertheless, the growth of the world population does not lose its dynamics. Hence, the united Europe is not threatened with the "demographic collapse". Immigration pressure will grow, because the EU constitutes an extremely attractive place to live for those seeking prosperity, freedom and personal security. A possible depopulation may only happen to those Member States that will consistently resist the migration pressure, although in the long run such actions are doomed to failure. Today, the European Union is not facing the challenge of depopulation but of effective, peaceful acculturation. 


\section{Bibliography}

CBOS (2012), Potrzeby prokreacyjne oraz preferowany i realizowany model rodziny, BS/61/2012, https://www.cbos.pl/SPISKOM.POL/2012/K_061_12.PDF [access on: 30.06.2019].

CBOS (2018), Zadowolenie $z \dot{z} y c i a$, No. 5, https://cbos.pl/SPISKOM.POL/2018/K_005_18.PDF [access on: 30.06.2019].

CBOS (2019), Zadowolenie z życia, No. 6, https://www.cbos.pl/SPISKOM.POL/201 9/K_006_19. PDF [access on: 30.06.2019].

Cieślińska E. (2014), Bezdzietność jako styl życia, "Pogranicze. Studia Społeczne”, No. XXIV.

Dolińska B. (2014), Bezdzietność. Perspektywa społeczno-kulturowa, Sopot.

Eurostat (2017), People in the EU - statistics on demographic changes, https://ec.europa.eu/eurostat/ statistics-explained/index.php/People_in_the_EU_-_statistics_on_demographic_changes\#Population_change_in_the_EU [access on: 20.06.2019].

Eurostat (2019a), Fertility statistics, https://ec.europa.eu/eurostat/statistics-explained/index. php?title=Fertility_statistics [access on: 20.06.2019].

Eurostat (2019b), Population change -demographic balance and crude rates at national level, http://appsso.eurostat.ec.europa.eu/nui/show.do?dataset=demo_gind\&lang=en [access on: 20.06.2019].

Jefferson, T. (1970), The declaration of independence, Achille J. St. Onge.

Komorowska E., Kukawska E. (2015), Bezdzietność z wyboru i jej związki z wybranymi zachowaniami konsumpcyjnego stylu życia mieszkańców wsi i miast, "Rozprawy Społeczne", No. 1(IX), pp. 70-78.

Malinowski B. (2000), Naukowa teoria kultury, [in:] Kultura i jej przemiany, Dzieła v. 9, B. Malinowski, Warszawa 2000.

Maslow A.H. (1990), Motywacja i osobowość, Warszawa.

Mason G. (1990), Virginia Declaration of Rights, Virginia Foundation for the Humanities and Public Policy.

Obuchowski K. (2000), Galaktyka potrzeb. Psychologia dążeń ludzkich, Poznań.

Rawls J. (1993), Political Liberalism, New York.

Slany K., Szczepaniak-Wiecha I. (2003), Fenomen bezdzietności we współczesnych wysoko rozwiniętych społeczeństwach, "Małżeństwo i Rodzina", No. 5.

Standard Eurobarometer 67 (2007, November), Public opinion in the Europena Union - Report, https://ec.europa.eu/commfrontoffice/publicopinion/index.cfm/ResultDoc/download/DocumentKy/63025 [access on: 20.06.2019].

Standard Eurobarometer 88 (2017, November), Public opinion in the Europena Union - Report, https://ec.europa.eu/commfrontoffice/publicopinion/index.cfm/ResultDoc/download/DocumentKy/82873 [access on: 20.06.2019].

Standard Eurobarometer 89 (2018, March), Public opinion in the Europena Union - Report, https:// ec.europa.eu/commfrontoffice/publicopinion/index.cfm/ResultDoc/download/DocumentKy/83546 [access on: 20.06.2019].

Standard Eurobarometer 273 (2007, February), European social reality - Report, https://ec.europa. $\mathrm{eu} /$ commfrontoffice/publicopinion/index.cfm/ResultDoc/download/DocumentKy/54560 [access on: 20.06.2019].

Standard Eurobarometer 279 (2007, February), Poverty and exclusion - Report, https://ec.europa. $\mathrm{eu} / \mathrm{comm}$ rontoffice/publicopinion/index.cfm/ResultDoc/download/DocumentKy/54575 [access on: 20.06.2019].

Szukalski P. (2003), Bezdzietność w Europie, “Wiadomości Statystyczne”, No. 1. 
Abstract: This is a common knowledge that demographic trends in the EU Member States does not ensure the substitutability of generations. Trying to explain the situation we usually point at cultural changes. Presuming that everyone looks for a meaningful life that brings satisfaction and sense we shall ask if contemporary European perceive parenthood as an important condition of that kind of life. The aim of the article is to test the correlation between the life satisfaction and a low fertility rate in the European Union countries, in general, and in Poland, in particular. The relevant data were provided by the Eurobarometer and CBOS.

Keywords: fertility rate in the EU; life satisfaction; demographic crisis

Article submitted: 1.07.2019; article accepted: 20.10.2019. 